\title{
Effect of planting density and training on plant health and seed quality of bell pepper (Capsicum annuum L.) under protected conditions
}

\author{
Manohar Lal ${ }^{1 *}$, H.S. Kanwar ${ }^{1}$, Rajesh Kanwar ${ }^{1}$ and Chaman Lal ${ }^{2}$ \\ ${ }^{1}$ Department of Seed Science and Technology, Dr. Y.S. Parmar University of Horticulture and Forestry Nauni, \\ Solan-173230 (Himachal Pradesh), INDIA \\ ${ }^{2}$ Department of Social Sciences, Dr. Y.S. Parmar University of Horticulture and Forestry, Nauni, Solan - 173230 \\ (Himachal Pradesh), INDIA \\ Corresponding author. E-mail: manoharlal647@gmail.com
}

Received: October 26, 2015; Revised received: April 01, 2016; Accepted: July 11, 2016

\begin{abstract}
A study was conducted at the Department of Seed Science and Technology, Dr. Y. S. Parmar University of Horticulture and Forestry, Nauni, Solan (H.P.), India during Kharif 2012 to evaluate the effects of the different planting densities and training systems on plant health (powdery mildew severity) and seed quality of bell pepper cv. Solan Bharpur under protected conditions (polyhouse). Experiment was laid out in naturally ventilated polyhouse using three different planting densities $\left(S_{1}-45 \times 15 \mathrm{~cm}, S_{2}-45 \times 30 \mathrm{~cm}\right.$ and $\left.S_{3}-45 \times 45 \mathrm{~cm}\right)$ and four training levels $\left(T_{1}-\right.$ single shoot, $T_{2}$ - two shoots, $T_{3}$ three shoots and $\mathrm{T}_{4}$ - four shoots)with three replicates. The combination $\mathrm{S}_{2} \mathrm{~T}_{2}$ (plants spaced at $45 \times 30 \mathrm{~cm}$ and trained to two shoots) was found superior over all other treatments in terms of seed yields i.e. per plant and per hectare $(18.00 \mathrm{~g}$ and $959.87 \mathrm{~kg}$, respectively) and was at par with important quality characters. The treatment combination $\mathrm{S}_{3} \mathrm{~T}_{1}$ (plant spaced at $45 \times 45 \mathrm{~cm}$ and trained to single shoot) resulted in least powdery mildew severity $(21.21 \%)$ and performed best for seed quality characters viz. 1000 seed weight, germination percentage, seedling length, seedling dry weight, seedling vigour index-I \& II (6.32 g, 95.75\%, $10.86 \mathrm{~cm}, 3.26 \mathrm{mg}, 1039.77$ and 312.34, respectively) but it gave lower seed yield and thus it is uneconomic. Therefore, planting density $45 \times 30 \mathrm{~cm}$ in combination with two shoot training system can be recommended for commercial seed production of bell pepper under protected conditions.
\end{abstract}

Keywords: Bell pepper, Planting density, Powdery mildew severity, Seed quality, Training level, Yield

\section{INTRODUCTION}

Bell pepper belongs to family solanaceae, is adapted to a wide variety of climates but production is concentrated in a few warm and rather dry areas (Thouraya and Leila, 2015). The diverse climate of India and agro -climatic conditions of the plains sometimes proves to be non-conducive for seed production of bell pepper due to various biotic and abiotic stresses. The crops grown in open field are often exposed to fluctuating levels of temperature, rain, humidity, wind flow etc. which may affect the bell pepper seed production adversely.

These complications in seed production can be overcome by carrying out the seed production programme in the protected environment with improved agrotechniques. Green house, the latest word in Indian agriculture is one such mean, where the plants are grown under controlled or partially controlled environment and thus polyhouses or greenhouses can be utilized to get the higher yields of quality seed. In greenhouse cultivation appropriate cultural practices such as plant densities and training systems are emphasized to enhance the productivity by utilizing the available space and resources. Optimum plant density allows doing cultural practices easily and reduces the competition among the plants for resources and also prevents the diseases to proliferate. By choosing appropriate plant density one can properly utilize his land by accommodating more number of plants over an area. The yield of sweet pepper has been reported to be dependent on the number of plants accommodated per unit area (Duimovic and Bravo, 1979). Spatial arrangement of plants is a crop management practice that has been used to increase yield per unit area in greenhouse sweet pepper (Ahirwar and Hedau, 2015). On the other hand, a suitable training system will not only facilitate better management and uniform light to the plants, but also permit closer planting, early ripening of fruits and give higher yields of good quality seed. In greenhouse bell pepper fruit development is controlled by limiting the branching pattern to 2, 3 or 4 main stems (Jovicich et al., 2004). Training systems varies with different growth habits and plant densities. A good combination of spacing and training level enhance the air circulation which reduces the relative humidity and thus prevent the disease proliferation. Therefore developing appropriate training and spacing practice under protected conditions can positively accelerate the production level in the same piece of land with similar inputs as required under open field conditions. Moreover, 
seed production under the polyhouse conditions with such agro-techniques has been practiced only in few crops. Therefore, keeping in view the above facts, the present study was planned to find out the optimum planting density and training system for quality seed production of bell pepper under the protected conditions.

\section{MATERIALS AND METHODS}

The present investigation was carried out in the Department of Seed Science and Technology, Dr. YS Parmar University of Horticulture and Forestry, Nauni, Solan during Kharif 2012 in bell pepper cv. Solan Bharpur. The experiment was laid in Randomized Complete Block Design (Factorial) in field and completely randomized design (Factorial) in laboratory with four replicates. The seedlings were transplanted at three planting densities $\left(\mathrm{S}_{1}-45 \times 15 \mathrm{~cm}, \mathrm{~S}_{2}-45 \times 30 \mathrm{~cm}\right.$ and $S_{3}-45 \times 45 \mathrm{~cm}$ ) in naturally ventilated (top and side ventilated) polyhouse equipped with the drip irrigation system. After the establishment, the plants were trained to four levels (T) viz., $\mathrm{T}_{1}$ (single shoot), $\mathrm{T}_{2}$ (two shoots), $\mathrm{T}_{3}$ (three shoots) and $\mathrm{T}_{4}$ (four shoots). Recommended doses of manures and fertilizers were applied. The observations in field were made on five randomly selected plants from each replication. Per cent disease index (PDI) was calculated to assess the powdery mildew severity by using the formula given by Wheeler (1969) based on the leaf area affected scale, starting from peak vegetative stage and subsequently taken after 15 days interval as proposed by Ullasa et al. (1981) i.e. 1 no symptoms; 2 with $10 \%$ leaf affected; 3 with $11-20 \%$ of leaf area affected; 4 with $21-50 \%$ of the leaf area affected and 5 with $51 \%$ or more of leaf area affected.

For seed yield parameters, the seeds were extracted to calculate number of seeds per fruit. Seeds were dried to $8 \%$ moisture content in shade then weighed and averaged to work out seed yield per plant and per hectare. In the laboratory, the test weight (1000 seed weight) was worked out. From all replicates 100 seeds

$$
\text { PDI }=\frac{\begin{array}{l}
\text { Sum of numerical values of all } \\
\text { grades }
\end{array}}{\text { Number of observed plants }} \times \frac{100}{\begin{array}{l}
\text { Maximum } \\
\text { ease rating }
\end{array}} \text { dis- }
$$

were subjected to germination at $25^{\circ} \mathrm{C}$ using paper roll method to assess the percent seed germinated, seedling length, seedling dry weight (dried at $60{ }^{\circ} \mathrm{C}$ for 48 hours) and seedling vigour. The statistical analysis of the observations was done as per design of the experiment as suggested by Gomez and Gomez (1984).

\section{RESULTS AND DISCUSSION}

Effect on health of bell pepper: Bell pepper (Capsicum annuum L.) grown at spacing $45 \times 45 \mathrm{~cm}$ and trained to single shoot were least susceptible to powdery mildew severity $21.21 \%$ (Table 1 ). Savinove

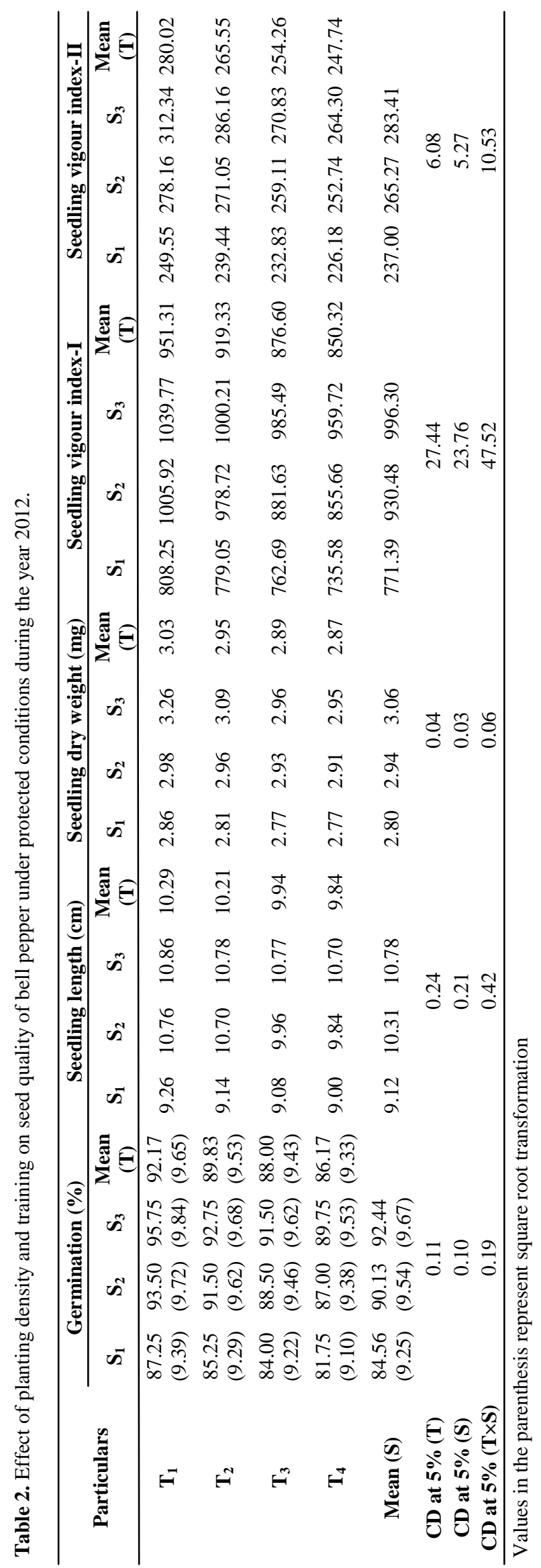


Table 1. Effect of planting density and training on powdery mildew severity and seed yield of bell pepper under protected conditions during the year 2012 .

\begin{tabular}{|c|c|c|c|c|c|c|c|c|c|c|c|c|c|c|c|c|}
\hline \multirow{2}{*}{ Particulars } & \multicolumn{4}{|c|}{$\begin{array}{c}\text { Powdery mildew severity } \\
(\%)\end{array}$} & \multicolumn{4}{|c|}{ Number of seeds/ fruit } & \multicolumn{4}{|c|}{ Seed yield/ plant (g) } & \multicolumn{4}{|c|}{ Seed yield/ha (kg) } \\
\hline & $\mathbf{S}_{1}$ & $\mathbf{S}_{\mathbf{2}}$ & $\mathbf{S}_{\mathbf{3}}$ & $\begin{array}{c}\text { Mean } \\
(\mathbf{T})\end{array}$ & $\mathbf{S}_{1}$ & $\mathbf{S}_{2}$ & $\mathbf{S}_{3}$ & $\begin{array}{c}\text { Mean } \\
(\mathbf{T})\end{array}$ & $\mathbf{S}_{1}$ & $\mathbf{S}_{2}$ & $\mathbf{S}_{3}$ & $\begin{array}{l}\text { Mea } \\
\text { n (T) }\end{array}$ & $\mathbf{S}_{1}$ & $\mathbf{S}_{\mathbf{2}}$ & $\mathbf{S}_{\mathbf{3}}$ & $\begin{array}{c}\text { Mean } \\
(\mathbf{T})\end{array}$ \\
\hline $\mathrm{T}_{1}$ & $\begin{array}{l}22.26 \\
(4.82)\end{array}$ & $\begin{array}{l}21.49 \\
(4.74)\end{array}$ & $\begin{array}{l}21.21 \\
(4.71)\end{array}$ & $\begin{array}{l}21.65 \\
(4.76)\end{array}$ & 167.20 & 193.52 & 198.14 & 186.29 & 7.55 & 15.47 & 11.89 & 11.64 & 805.62 & 825.35 & 422.62 & 684.53 \\
\hline $\mathrm{T}_{2}$ & $\begin{array}{l}26.49 \\
(5.24)\end{array}$ & $\begin{array}{l}21.33 \\
(4.73)\end{array}$ & $\begin{array}{l}21.40 \\
(4.73)\end{array}$ & $\begin{array}{l}23.07 \\
(4.90)\end{array}$ & 162.10 & 189.73 & 193.90 & 181.91 & 8.09 & 18.00 & 13.08 & 313.05 & 862.40 & 959.87 & 465.04 & 762.44 \\
\hline $\mathrm{T}_{3}$ & $\begin{array}{l}25.09 \\
(5.11)\end{array}$ & $\begin{array}{l}21.75 \\
(4.77)\end{array}$ & $\begin{array}{l}21.56 \\
(4.75)\end{array}$ & $\begin{array}{l}22.80 \\
(4.88)\end{array}$ & 156.63 & 187.18 & 190.88 & 178.23 & 8.10 & 16.74 & 15.59 & 13.48 & 863.51 & 892.96 & 554.21 & 770.22 \\
\hline $\mathrm{T}_{4}$ & $\begin{array}{l}26.86 \\
(5.28)\end{array}$ & $\begin{array}{l}21.92 \\
(4.79)\end{array}$ & $\begin{array}{l}22.08 \\
(4.80)\end{array}$ & $\begin{array}{l}23.62 \\
(4.96)\end{array}$ & 152.11 & 182.37 & 186.64 & 173.71 & 7.62 & 15.63 & 15.93 & 313.06 & 813.24 & 833.39 & 566.19 & 737.61 \\
\hline Mean (S) & $\begin{array}{l}25.17 \\
(5.11)\end{array}$ & $\begin{array}{l}21.62 \\
(4.75)\end{array}$ & $\begin{array}{l}21.56 \\
(4.75)\end{array}$ & & 159.51 & 188.20 & 192.39 & & 7.84 & 16.46 & 14.12 & & 836.19 & 877.89 & 502.01 & \\
\hline $\mathrm{CD}$ at $5 \%(\mathrm{~T})$ & & 0 . & 11 & & & 1.0 & 00 & & & & 79 & & & & .71 & \\
\hline $\mathrm{CD}$ at $5 \%(\mathrm{~S})$ & & 0. & 09 & & & 0.8 & 86 & & & & 68 & & & & .32 & \\
\hline $\begin{array}{l}\mathrm{CD} \text { at } 5 \% \\
(\mathrm{~T} \times \mathrm{S})\end{array}$ & & 0 . & 19 & & & 1.7 & 73 & & & 1.3 & 36 & & & & .64 & \\
\hline
\end{tabular}

(1978) reported least incidence of fruit rot in capsicum at wider spacing. Powdery mildew caused by Leveillula taurica is considered as a major disease (Bidari et al., 1985). Low temperature after the dry spell is predisposing factor for this disease to proliferate. Yarwood et al. (1954) considered that among plant pathogens the powdery mildews have low optimum temperature averaging $21^{\circ} \mathrm{C}$. Wider spaced plants with low shoot density allow the air and light pass through them which hinder the conidia to germinate and also optimum spacing between the plants prevents the disease to spread from infected plant to healthy one. Moreover, adequate plant spacing also helps to obtain good coverage when fungicides are used. On the other hand high plant and shoot density create the congenial environment for the proliferation of disease.

Effect on seed yield : The combination $\mathrm{S}_{3} \mathrm{~T}_{1}(45 \times 45$ $\mathrm{cm}$ and single shoot) produced fruits with maximum number of seeds per fruit (198.14). Wider spaced and single shoot plants bear larger sized fruits having bold seeds and also, the size of fruit is correlated to number of seeds (Wien, 1997). But according to Khurana et al. (2002) spacing has no effect on number of seeds per fruit in capsicum. Significantly higher seed yields per plant and per hectare $(18.00 \mathrm{~g}$ and $959.87 \mathrm{~kg}$, respectively) were resulted from $\mathrm{S}_{2} \mathrm{~T}_{2}$ i.e. plants spaced at $45 \times 30 \mathrm{~cm}$ with two shoots (Table 1). Sanchez et al. (1993) and Lal et al. (2014) in bell pepper reported maximum seed yield per plant at wider spacing. While Singh et al. (1989) and Khurana et al. (2002) in chilli reported lower seed yield per $\mathrm{m}^{2}$ and per hectare with wider spacing. Well management of pest and diseases, favourable conditions prevails for healthy growth and extended growing season in the polyhouse added up to the production of quality seed. Moreover the $\mathrm{CO}_{2}$ released by the plants during respiration could not escape easily from the polyhouse. The fact that $\mathrm{C}_{3}$ plants responds to higher $\mathrm{CO}_{2}$ concentration by showing in- creased rates of photosynthesis leading to higher productivity has been used for greenhouse crops such as bell pepper and tomatoes. Another role polyhouse played is that it maintained the temperature during the growth cycle resulted in healthy growth of the plants. The dark reactions being enzymatic are temperature controlled and optimum temperature ranging from 25$35{ }^{\circ} \mathrm{C}$ is required for good photosynthetic rate (Rani et al., 2011). The occurrence of cool temperatures during fruit set could also reduce the number of seeds per fruit, and thus lower seed yield (Rylski, 1973). In the field bell pepper can be harvested over a period of 2-3 months but in greenhouse production season can be extended for 8 months (Wien, 1997). This extended crop season resulted in the higher seed yields of bell pepper.

Effect on seed vigour attributes: The maximum 1000 seed weight, germination percentage, seedling length, seedling dry weight, seedling vigour index-I \& II (6.32 g, $95.75 \%, 10.86 \mathrm{~cm}, 3.26 \mathrm{mg}, 1039.77$ and 312.34 , respectively) were recorded from spacing $45 \times 45$ and single shoot training system (Table 2). The results for 1000 seed weight are in conformity with the findings of Everett and Subramanya (1985) and Dharmatti and Kulkarni (1988), who reported that wider spacing resulted in higher 1000 seed weight in bell pepper. Sanchez et al. (1993) recorded 73-88 \% germination in bell pepper influenced by plant spacing. Wide spaced with single stem plants conditioned with favourable environment of polyhouse provided better opportunity to increase the efficacy of light and photosynthesis. Besides this, plants are less prone to competition for the resources which lead to healthy plants and bigger fruits and ultimately resulted in healthier and bolder seeds of good quality. Tabasi et al. (2011) also concluded that that less fruit on clusters and native tomato plants causing enlargement of the fruit, as a result 1000 weight of seeds and power of germination would be increased for the next generation. Piccolo et al. (1993) 
reported that increasing the 1000 grain weight results in increasing the fresh and dry weight of tomato seedling. Sajjan et al. (2004) in okra observed higher seedling length and dry weight with wider spaced plants. Therefore it can be concluded that bold seeds of bell pepper with more test weight produces the more vigorous seedlings. Optimum plant density and shoot pruning increase the quality of fruit and seed which in turn leads to better establishment of more vigorous plants of polyhouse grown bell pepper.

\section{Conclusion}

From the present study it can be concluded that the treatment combination $\mathrm{S}_{2} \mathrm{~T}_{2}$ (bell pepper plants spaced at $45 \times 30 \mathrm{~cm}$ and trained to two shoots) was found superior for seed yield whereas $S_{3} T_{1}$ was superior for seed health and also for seed vigour attributes such as 1000 seed weight, germination and seedling vigour but resulted in lower yields. Moreover the treatment combination $\mathrm{S}_{2} \mathrm{~T}_{2}$ was at par with the best treatments for most of the other important characters. Therefore planting density $S_{2}(45 \times 30 \mathrm{~cm})$ in combination with training system $\mathrm{T}_{2}$ (two shoots) may be recommended to get higher yields in commercial seed production of bell pepper under protected conditions.

\section{REFERENCES}

Ahirwar, C.S. and Hedau, N.K. (2015). Effect of shoot pruning on yield and quality attribute of a winter capsicum (Capsicum annum L.) crops in hills protected condition. Asian Journal of Bio Science, 10(1): 1-5.

Bidari, V.B., Bhat, B.N. and Hegde, R.K. (1985). Reaction of different genotypes of chilli against Leveillula taurica (Lev.) Arn. Indian Journal of Agricultural Sciences, 55(9): 557-559.

Dharmatti, P.R. and Kulkarni, G.N. (1988). Effect of nutrition, spacing and picking on seed yield and seed quality in bell pepper. Seed Research, 16(2): 148-151.

Duimovic, M.A. and Bravo, M.A. (1979). Effects of nitrogen and spacing on the yields and quality of bell pepper. Investigation Agraria, 6: 99-103.

Everett, P.H. and Subramanya, R. (1985). Pepper production as influenced by plant spacing and nitrogen and potassium rates. Citrus and Vegetable Magazine, 48(4): 42-47.

Gomez, K.A. and Gomez, A.A. (1984). Statistical Procedure for Agricultural Research. New York: Jonn Wily, 690p.

Jovicich, E., Cantliffe, D.J. and Stofella, P.J. (2004). Fruit yield quality of greenhouse grown bell pepper as influenced by density, container and trellis system. Horteh., 14(4): 507-513.
Khurana, D.S., Parmar, P., Hundal, J.S. and Kanwar, J.S. (2002). Effect of plant population density and parental row ratio on hybrid seed production in chilli (Capsicum annuum L.). Journal of Research, PAU, 39(4): 499-503.

Lal, M., Kanwar, H.S. and Kanwar, R. (2014). Impact of spacing and training on seed yield of capsicum, Capsicum annuum L. under protected conditions. International Journal of Farm Sciences 4(3): 42-48.

Piccolo, A., Celano, G, and Pietamellara, G. (1993). Effect of fractions of coal derived humic substances on seed germination and growth of seedlings (Lacteal sativa and Lycopersicum esculentum). Biologia Plantarum, 16: 11-15.

Rani, C., Chawla, S. and Rana, M.K. (2011). Photosynthesis: Physio-Biochemistry and Biotechnology of Vegetable Crops. New India Publishing Agency, New Delhi, pp. 5386.

Rylski, I. (1973). Effect of night temperature on shape and size of sweet pepper (Capsicum annuum L.). Journal of American Society of Horticultural Science, 98: 149-152.

Sajjan, A.S., Shekaragouwda, M. and Biradar, B.D. (2004). Effect of sowing dates and spacing and nitrogen levels on seed yield and quality of okra (Abelmoschus esculentus L. Moench). Seed Research, 32(2): 118-121.

Sanchez, V.M., Sundstroml, F.J. and Lang, N.S. (1993). Plant size influences bell pepper seed quality and yield. Horticulture Science, 28(8): 809-811.

Savinove, N.I. (1978). Characteristics of fruit formation in tomatoes in relation to the environment: Genotip 1 Sreda V Selektsil Telpich Tomato. Leningrad USSR, pp.118-123.

Singh, S.B., Singh, T., Singh, B.N. and Singh, S.S. (1989). Growth and yield of chilli (Capsicum annuum L.) in relation to zinc levels and number of seedlings/hill. Horticulture Science, 18(1-2): 113-118.

Tabasi, A., Nemati, H., Tehranifar, A. and Akbari, M. (2011). The Effects of shrub pruning and fruit thinning on seed germination and seedling of tomato in the next generation (Lycopersicon esculentum Mill). Journal of Biological and Environmental Science, 5(14): 105-110.

Thouraya, R. and Leila, R. (2015). Growth and yield responses of two Tunisian pepper (Capsicum annuum L.) varieties to salinity and drought stress. International Journal of Innovation and Scientific Research, 14(2): 159-167.

Ullasa, B.A., Rawal, R.D., Sohi, H.S. and Singh, D.P. (1981). Reaction of sweet pepper genotypes to anthracnose, cercospora leaf spot and powdery mildew. Plant Disease, 65: 600-01.

Wheeler, B.E.J. (1969). An Introduction to Plant Disease. John Wiley and Sons Ltd., London. 301p.

Wien, H.C. (1997). Peppers: The Physiology of Vegetable Crops. CAB International, UK, pp. 259-293.

Yarwood, C.E., Sidky, S., Cohen, M. and Santilli, V. (1954). Temperature relations of powdery mildews. Hilgardia, 22: 603-622. 